\title{
Analisis Bentuk Kepemilikan Bahasa Patani di Halmahera Tengah
}

\author{
Nurain Jalaluddin ${ }^{1)}$, Ety Duwila ${ }^{2)}$ \\ ${ }^{1}$ Universitas Khairun \\ jalaluddinnurain@gmail.com \\ ${ }^{2}$ Universitas Khairun \\ etyagusabid@gmail.com
}

Received: $27^{\text {th }}$ November 2021| Revised: $21^{\text {st }}$ December 2021| Accepted: $27^{\text {th }}$ December 2021

Email Correspondence: jalaluddinnurain@gmail.com

\begin{abstract}
Abstrak
Penelitian ini bertujuan untuk menggambarkan bentuk-bentuk kepemilikan dalam bahasa Patani. Teknik pengumpulan data menggunakan tiga tahapan, yaitu metode penyediaan data, metode analisis data dan metode penyajian hasil analisis. Berdasarkan hasil analisis data diperoleh bentuk-bentuk kepemilikan bahasa Patani sebagai berikut: 1) bentuk kepemilikan persona pertama tunggal berupa: -g, -nik, -nak; 2) Bentuk kepemilikan persona pertama jamak eksklusif berupa: -mam; 3) bentuk kepemilikan persona pertama jamak inklusif berupa: -r, -nir, -nor; 4) bentuk kepemilikan persona kedua tunggal berupa: -m, nim, -nam; 5) bentuk kepemilikan persona kedua jamak berupa: -me, -nimi, -nomo; 6) bentuk kepemilikan persona ketiga tunggal berupa: i-, $\quad$-ni, -no; 7) bentuk kepemilikan persona ketiga jamak berupa: -re, -niri, dan -noro. Bentuk kepemilikan tersebut sebagian besar merupakan enklitik. Bentuk kepemilikan yang berbentuk proklitik, yaitu bentuk kepemilikan persona ketiga tunggal i-. Bentuk kepemilikan i- selain sebagai persona ketiga tunggal juga merupakan bentuk kepemilikan.
\end{abstract}

Kata kunci: pronomina persona, kepemilikan, proklitik, enklitik

\begin{abstract}
This study aims to describe the possessive forms of Patani language. In describing the data, the researchers apply the three method stages; the method of data acquisition, data analysis and presentation of analysis. The result of the study shows that the possessive forms of Patani language are 1) :-g, -nik, nak for the first person singular; 2) the possessive forms of first person plural for exclusive is only mam and there are three forms for inclusive: -r, -nir, -nor; 4) for second person singular are :-m, -nim, -nam; 5) the second person plural are -me, -nimi, -nomo; 6) the possessive forms : I -, -ni, -no are for the third person singular; 7) for third person plural, the forms are -re, -niri, and -noro. Most of the possessive forms are enclitic, the only proclitic in this study is the possessive form of third person singular I-.
\end{abstract}

Keywords: personal pronouns, possessive form, proclitic, enclitic

Online at https://journal.universitasbumigora.ac.id/index.php/humanitatis/

DOI : https://doi.org/10.30812/humanitatis.v8i1.1558 


\section{PENDAHULUAN}

Bahasa merupakan salah satu unsur penting selain sistem religi, ilmu pengetahuan, kesenian, dan unsur lainnya yang mendukung tujuh unsur penting dalam kebudayaan suatu masyarakat. Bahasa menjadi begitu penting karena fungsi dan kegunaan dalam membentuk jati diri pengguna bahasa, menjadi sarana komunikasi dan interaksi dalam suatu daerah atau masyarakat sebagaimana yang dikemukakan oleh (Koentjono, 1982) bahwa bahasa adalah sistem lambang bunyi yang arbitrer yang dipergunakan oleh sekelompok anggota masyarakat untuk berkomunikasi, berinteraksi dan mengidentifikasikan diri.

Salah satu hakikat bahasa yaitu arbitrer menjadikan bahasa yang ada di dunia ini menjadi banyak jumlahnya dan beragam. Di Indonesia, jumlah bahasa daerah kurang lebih berjumlah 700 bahasa. Jumlah bahasa daerah ini tersebar dari Sabang sampai Merauke yang secara tidak langsung merepresentasikan suku bangsa mereka. Dalam PP no 57 tahun 2014 pasal 8 menegaskan di antaranya bahwa bahasa daerah berfungsi sebagai pembentuk kepribadian suku bangsa, peneguh jati diri kedaerahan, juga sebagai sarana komunikasi dalam keluarga dan masyarakat daerah. Bahasa daerah sebagai perwakilan jadi diri pengguna memiliki ciri dan keunikan tersendiri yang mencerminkan masyarakat atau suku bangsa (57TAHUN2014PP@Jdih.Kemenkeu.Go.Id, n.d.).

Maluku Utara memiliki kurang lebih 32 bahasa daerah yang berdasarkan ciri dan keunikannya dikelompokkan ke dalam dua rumpun bahasa, yakni rumpun Austronesia dan rumpun Non-Austronesia. Rumpun Austronesia dituturkan di bagian selatan pulau Halmahera dan bahasa-bahasa yang termasuk dalam rumpun Non-Austronesia dituturkan di bagian utara pulau Halmahera. Taber dalam (Imelda, 2017) menyatakan bahwa bahasa Galela, Gamkonora, Waiyoli, Ibu,Laba, Loloda, Makian Luar, Modole, Kao, Pagu, Sahu, Tabaru, Ternate, Tidore, dan Tobelo yang terdapat di utara Halmahera merupakan kelompok rumpun Non- Austronesia, sementara bahasa-bahasa yang termasuk dalam rumpun bahasa Austronesia yang terletak di selatan Halmahera, seperti bahasa Patani, Maba, Buli, Gane, Gebe, Makian Dalam, dan Sawai.

Bahasa-bahasa yang termasuk dalam rumpun Non-Austronesia dan Austronesia di Maluku Utara sebagian besar memperlihatkan ciri yang mirip dalam gramatika khususnya bentuk frase nomina posesif, yaitu berstruktur Menerangkan-Diterangkan (MD). Sebagai contoh, dalam bahasa Ternate untuk menyatakan anak saya diungkapkan dengan bentuk fajaru ma ngofa yang terbentuk dari kata fajaru 'saya', ma 'posesif', dan ngofa 'anak'. Dalam bahasa Galela diungkapkan dengan ai ngopa yang terbentuk dari bentuk ai 'pemarkah pertama tunggal/saya' dan ngopa 'anak'. Dalam bahasa Loloda diungkapkan dengan bentuk ngoji ngoaka dari bentuk ngoji 'saya' dan ngoaka 'anak'. Dalam bahasa Sula yang merupakan bahasa rumpun Austronesia juga mempunyai struktur frase yang sama yaitu berstruktur

Online at https://journal.universitasbumigora.ac.id/index.php/humanitatis/ 
MD. Sebagai contoh, untuk menyatakan anak saya dipakai bentuk ak nana 'anak saya' yang terbentuk dari kata $a k$ 'saya' dan nana 'anak'. Bentuk frase nomina posesif bahasa-bahasa ini turut berpengaruh pada bentuk posesif bahasa Melayu yang digunakan di Maluku Utara atau biasa disebut bahasa Melayu Ternate. Sebagai contoh untuk menyatakan anak saya/anakku digunakan bentuk kita pe ana (kita adalah pronomina persona pertama tunggal, pe merupakan bentuk kepunyaan dan ana adalah nomina termiliki).

Secara struktur, kemiripan dalam pembentukan posesif mirip tetapi dalam bahasa Patani yang merupakan bahasa rumpun Austronesia terdapat perubahan. Perubahan itu terjadi pada bentuk pronomina persona menjadi penanda posesif yang menandakan pronomina persona. Contoh bentuk yang memperlihatkan adanya pola yang berbeda seperti uraian di atas dapat dilihat pada bentuk fyan 'saya pergi' yang dibentuk dari aya 'saya' (pronomina persona pertama tunggal) + fan'pergi' (sebagai verba) fyan. Untuk bentuk kepemilikan, pronomina persona diungkapkan dalam bentuk yang berbeda yang tidak memperlihatkan ciri pronomina persona. Misalnya, bentuk kepemilikan anik buk 'buku saya' dan anak yof 'sagu saya'. Dari kedua contoh bentuk kepemilikan tersebut, anik dan anak merupakan bentuk posesif persona pertama tunggal. Keunikan bentuk posesif bahasa Patani ini yang akan menjadi kajian dalam penelitian ini.

Berdasarkan uraian di atas, dapat dirumuskan permasalahan dalam penelitian ini, yaitu bagaimana bentuk-bentuk kepemilikan bahasa Patani dengan tujuan untuk menggambarkan secara detail entukbentuk kepemilikan bahasa Patani. Ini penting dilakukan untuk memberikan gambaran tentang karakteristik bahasa Patani. Dengan demikian hasil penelitian ini dapat bermanfaat baik secara teoritis, yakni akan memperkaya khazanah penulisan struktur bahasa, khusunya bahasa daerah di Maluku Utara dan manfaat secara praktis, yakni dapat dijadikan sebagai bagian dari bentuk kajian struktur mata kuliah linguistik.

Kajian tentang struktur bahasa Patani sepanjang pengamatan peneliti belum dilakukan. Hal ini yang mendorong perlu dilakukannya penelitian. Meskipun demikian ada beberapa kajian struktur bahasa daerah yang dapat dijadikan acuan dalam mengkaji bentuk kepemilikan bahasa Patani.

Kajian bentuk konstruksi posesif yang dilakukan oleh (Duwila, 2020) dengan judul "Konstruksi Posesif dalam Bahasa Melayu Ternate". Kajian ini memperlihatkan sembilan pola konstruksi posesif di dalam bahasa Melayu Ternate. Kajian tentang konstruksi posesif juga dilakukan oleh (Salamun, 2019) dengan judul "Perbandingan Pola Konstruksi Posesif Dialek Ambon dengan Bahasa Indonesia Baku". Hasil tulisan ini memperlihatkan bahwa terdapat perbedaan pola konstruksi posesif antara keduanya. Perbedaan tersebut dilihat pada prossesor dan possesum yang berbeda. Dalam kaitannya dengan

Online at https://journal.universitasbumigora.ac.id/index.php/humanitatis/

DOI $\quad$ : https://doi.org/10.30812/humanitatis.v8i1.1558 
penelitian ini, kedua kajian tentang konstruksi posesif tersebut dapat memberikan penjelasan lebih tentang kajian konstruksi posesif suatu bahasa.

Penelitian dengan judul Bentuk Kepemilikan Bahasa Patani akan secara detail mengulas bentukbentuk kepemilikan yang merupakan kajian sinkronis bahasa pada tataran morfologi dan sintaksis bahasa Patani Halmahera Tengah. Penelitian ini akan menggunakan pedekatan morfologi dan sintaksis. Pendekatan morfologi digunakan karena menyangkut bentuk kepemilikan yang keberadaannya dirangkaikan atau melekat dengan penanda yang memiliki dan bentuk yang dimiliki. Morfologi adalah bagian dari ilmu bahasa yang mempelajari seluk beluk bentuk kata serta pengaruh perubahan-perubahan bentuk kata terhadap golongan dan arti kata (Ramlan, 2001). Kata dapat berbentuk tunggal dan ada juga yang berbentuk kompleks. Kata yang berbentuk kompleks terjadi melalui proses morfologis berupa afiksasi, reduplikasi, maupun pemajemukan. Sehubungan dengan penelitian ini yang membahas bentuk kepemilikan dan pola nomina, dalam bahasa Patani bentuk kepemilikan berupa bentuk terikat yang keberadaannya dirangkaikan dengan bentuk dasar dan penanda persona atau dengan penanda persona saja. Dalam hal ini, proses pembentukan kata atau kajian morfologi menjadi penting sebagai pijakan dalam menganalisis bentuk kepemilikan bahasa Patani.

Konsep tentang posesif agar dapat membedah pola atau bentukan posesif dengan baik. Secara umum posesif adalah pemaknaan milik atas sesuatu. Sejalan dengan definisi posesif, Taylor dalam (Setiawan, 2016) menuturkan bahwa secara sederhana posesif merupakan hubungan seseorang dengan entitas atau sesuatu. Dengan kata lain, pola posesif terdiri dari dua unsur, yaitu unsur pemilik dan unsur entitas yang dimiliki. Contoh bentukan posesif dalam bahasa Indonesia yakni buku saya terlihat pola bentukan berupa buku yang merupakan sesuatu yang dimiliki dan saya berupa pronomina orang pertama di mana pola posesif dalam bahasa Indonesia yakni entitas mendahului pemilik. Dalam mengekspresikan bentukan atau pola posesif, banyak bahasa memilik bentukannya yang berbeda satu sama lain. Hal ini yang kemudian memberikan variasi bentukan posesif.

Kajian sintaksis digunakan untuk mengkaji pola kepemilikan bahasa Patani. Chaer dalam (Awaluddin, 2017) menjelaskan bahwa sintaksis adalah tataran linguistik yang disebut tata bahasa. sintaksis membicarakan kata dalam hubungannya dengan kata lain atau unsur-unsur lain sebagai satuan ujaran.

Perlu juga konsep tentang posesif agar dapat membedah pola atau bentukan posesif dengan baik. Secara umum posesif adalah pemaknaan milik atas sesuatu. Sejalan dengan definisi posesif, Taylor dalam (Setiawan, 2016) menuturkan bahwa secara sederhana posesif merupakan hubungan seseorang dengan entitas atau sesuatu. Dengan kata lain, pola posesif terdiri dari dua unsur, yaitu unsur pemilik dan

Online at https://journal.universitasbumigora.ac.id/index.php/humanitatis/

DOI : https://doi.org/10.30812/humanitatis.v8i1.1558 
unsur entitas yang dimiliki. Contoh bentukan posesif dalam bahasa Indonesia yakni buku saya terlihat pola bentukan berupa buku yang merupakan sesuatu yang dimiliki dan saya berupa pronomina orang pertama di mana pola posesif dalam bahasa Indonesia yakni entitas mendahului pemilik. Dalam mengekspresikan bentukan atau pola posesif, banyak bahasa memilik bentukannya yang berbeda satu sama lain. Hal ini yang kemudian memberikan variasi bentukan posesif.

\section{METODE PENELITIAN}

Metode yang digunakan dalam penelitian yaitu metode deskriptif kualitatif. Pendekatan ini dipilih karena berkaitan dengan tujuan penelitian ini, yakni mendeskripsikan bentuk bahasa Patani. Dengan pendekatan ini pula penelitian ini dimungkinkan memperoleh data-data kualitatif, dan selanjutnya akan diuraikan secara sistematis dengan mengacu pada gejala atau fakta yang muncul di lapangan.

Populasi dalam penelitian ini, yaitu penutur bahasa Patani yang terdapat di Kabupaten Halmahera Tengah. Sementara sampel penelitian hanya mengambil penutur bahasa Patani di kecamatan Patani Barat, khususnya Desa Banemo, Bobane Jaya dan Bobane Indah. Pemilihan sampel ini dilakukan karena secara struktur bahasa, bahasa Patani yang ada di empat kecamatan di Halmahera Tengah sama. Sehingga data yang akan diambil di Kecamatan Patani Barat telah mewakili keseluruhan data bahasa Patani.

Teknik pengumpulan data yang dilakukan, yaitu studi pustaka, observasi, dan wawancara dengan mengajukan pertanyaan berdasarkan kuesioner yang telah dipersiapkan. Penelitian ini dilakukan dalam tiga tahap yakni tahap persiapan meliputi penyelesaian administrasi dan perizinan penelitian, serta penjajakan awal penelitian dan melakukan studi pendahuluan. Tahap pelaksanaan berupa pengambilan data atau pengisian instrumen oleh responden dan tahap akhir meliputi pengolahan data, analisis data, dan laporan akhir.

Teknik pengolahan data yang dilakukan dalam penelitian ini dimulai dengan pengeditan data, pengodean data, dan pemrosesan. Pengeditan data dilakukan dengan maksud untuk memastikan bahwa jawaban yang diberikan oleh responden sesuai dengan perintah dan petunjuk pelaksanaan. Pengodean data dilakukan dengan tujuan untuk memudahkan proses pengolahan data. Teknik pengolahan terakhir berupa pemrosesan yang dimulai dengan melakukan pemasukan data dalam bentuk tabulasi. Analisis data dilakukan untuk mendeskripsikan bentuk dan pola kepemilikan bahasa Patani. Hasil analisis data disajikan secara informal yaitu pemaparan hasil analisis data dengan menggunakan kata-kata atau uraian biasa tanpa lambang-lambang. 


\section{HASIL DAN PEMBAHASAN}

Penjelasan tentang bentuk kepemilikan tidak terlepas dari bentuk pronomina suatu bahasa. Demikian juga dalam bahasa Patani, untuk memahami bentuk posesifnya, maka perlu digambarkan pronomina persona bahasa tersebut yang yang dapat dilihat pada tabel di bawah ini.

Tabel 1: Bentuk Pronomina bahasa Patani

\begin{tabular}{|c|c|c|c|c|}
\multicolumn{2}{c|}{} & \multicolumn{4}{|c|}{ Tabel 1: Bentuk Pronomina bahasa Patani } \\
\hline \multirow{2}{*}{ Orang } & \multicolumn{4}{|c|}{ Makna } \\
\cline { 2 - 5 } & \multirow{2}{*}{ Tunggal } & Netral & Eksklusif & Inklusif \\
\cline { 2 - 5 } & Aya & & Am & It \\
\hline Pertama & $\mathrm{Au}$ & $\mathrm{Meu}$ & & \\
\hline Kedua & $\mathrm{I}$ & $\mathrm{Si}$ & & \\
\hline Ketiga & &
\end{tabular}

Bentuk prononima bahasa Patani ini secara langsung memengaruhi bentuk posesifnya, karena dalam mendeskripsikan bentuk posesif terjadi pemendekan dari bentuk pronomima tiap orang, seperti pronomina persona pertama tunggal aya. Ketika menyatakan bentuk kepemilikan orang pertama tunggal maka akan mengalami pemendekan menjadi $a$-yang melekat dengan nomina yang dimiliki.Contoh lain, misalnya pronomina kedua jamak meu, ketika menyatakan kepemilikan orang kedua tunggal jamak maka akan menjadi me- yang melekat dengan nomina yang dimiliki.

Berdasarkan kajian terhadap data yang diperoleh, bentuk kepemilikan bahasa Patani berupa bentuk terikat yang keberadaannya selalu melekat dengan benda yang dimiliki yang didahului oleh penanda orang (persona). Dengan kata lain bentuk kepemilikan bahasa Patani merupakan bentuk enklitik karena dalam kata bentuk ini terletak di akhir setelah penanda persona diikuti benda yang dimiliki.

Bentuk kepemilikan bahasa Patani disesuaikan dengan pronomina persona. Berikut bentukbentuk kepemilikan tersebut.

\subsection{Bentuk Kepemilikan Persona Pertama Tunggal}

Bentuk kepemilikan persona pertama tunggal dalam bahasa Patani adalah -g, -nik, dan -nak. Bentuk -g digunakan ketika benda yang dimiliki merupakan anggota tubuh (kecuali bulu dan buah dada) dan kekerabatan (anak, kemenakan, dan saudara kandung dan saudara misan). Bentuk kepemilikan ini dapat dilihat pada contoh berikut.

\section{(1) a- fyele $-\mathbf{g}$ p1t hidung 1t.pos1 'hidung saya'}




\section{(2) $a$ - fono $\quad-g$ p1t kemenakan 1t.pos1 'kemenakan saya'}

Bentuk a- merupakan penanda persona pertama tunggal yang diikuti dengan fyele 'hidung' (anggota tubuh) contoh (1), fono 'kemenakan' (kekerabatan) contoh (2) sebagai benda yang dimiliki dan bentuk posesif -g sebagai bentuk terikat yang menyatakan kepemilikan persona pertama tunggal. Dalam penelitian ini, bentuk kepemilikan persona pertama tunggal -g disebut sebagai pos1 karena untuk membedakannya dengan bentuk kepemilikan persona pertama tunggal yang lain (bentuk -nik dan -nak).

Bentuk kepemilikan persona pertama tunggal berikutnya adalah -nik. Bentuk -nik digunakan pada benda hidup dan benda mati (benda bukan makanan dan benda yang tidak memiliki keterkaitan dengan makanan). Penggunaan bentuk kepemilikan -nik dapat dilihat pada contoh berikut.

(3) - -nik kaba:l p1t 1t.pos2 kambing 'kambing saya'

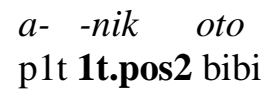
'bibi saya'

$$
\begin{aligned}
& \text { a- -nik tarapesa } \\
& \text { p1t 1t.pos2 kursi } \\
& \text { 'kursi saya' }
\end{aligned}
$$

Bentuk a- merupakan penanda persona pertama tunggal yang diikuti dengan bentuk -nik sebagai bentuk kepemilikan membentuk kata anik 'kepunyaan saya'. Bentuk kepemilikan ini terletak sebelum kata benda yang dimiliki kaba:l 'kambing' (3), oto 'bibi (istri paman) contoh (4) yang merupakan benda hidup dan tarapesa 'kursi' (5) yang merupakan benda mati. Bentuk kepemilikan -nik persona pertama tunggal ini disebut sebagai pos2 untuk membedakannya dari bentuk kepemilikan persona pertama tunggal -g dan -nak.

Bentuk kepemilikan -nak (pos3) digunakan untuk makanan dan benda lain yang memiliki keterkaitan dengan makanan. Berikut contoh penggunaan bentuk -nak.

a- -nak takale sinanga

p1t 1t.pos3 ayam goreng

'ayam goreng saya' (contoh makanan)

$$
\text { a- -nak gigyolo }
$$

p1t 1t.pos3 sendok

'sendok saya' (contoh benda yang memiliki keterkaitan dengan makanan) 
Bentuk a- merupakan penanda persona pertama tunggal yang diikuti dengan -nak sebagai bentuk kepemilikian membentuk kata anak 'kepunyaan saya'. Benda yang dimiliki yang mengikuti anak merupakan benda yang berupa makanan takale sinanga 'ayam goreng' contoh (6) dan benda yang memiliki keterkaitan dengan makanan, gigyolo 'sendok' seperti contoh (7) di atas. Pada contoh (6), takale sinanga 'ayam goreng' terbentuk dari kata takale yang artinya 'ayam' yang merupakan benda hidup yang bentuk kepemilikannya adalah -nik tetapi karena benda ini sudah dalam bentuk makanan dalam konteks di atas, sehingga penggunaan bentuk kepemilikan yang digunakan adalah bentuk -nak).

\subsection{Bentuk Kepemilikan Persona Pertama Jamak Eksklusif dan Inklusif}

Pronomina persona pertama jamak dalam bahasa Patani terbagi atas persona pertama jamak eksklusif dan persona pertama jamak inklusif. Bentuk kepemilikan persona jamak eksklusif hanya memiliki satu bentuk kepemilikan, yaitu -mam sesuai dengan benda yang dimilikinya.

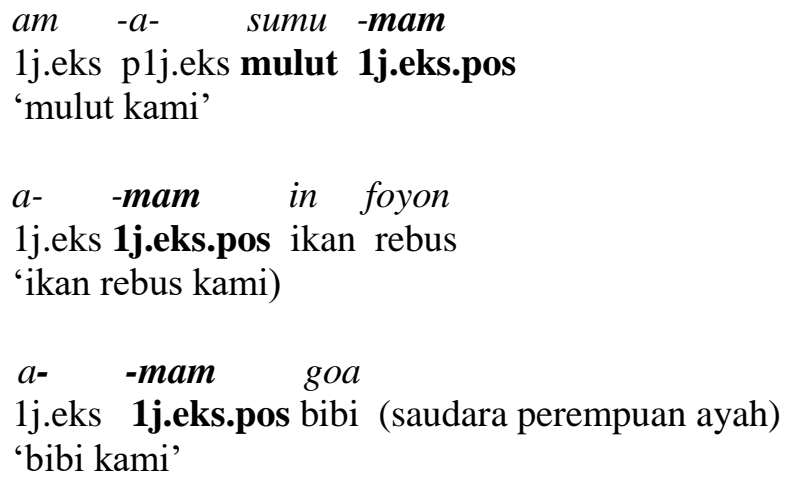

Bentuk kepemilikan -mam, bila digunakan dengan benda berupa anggota tubuh atau kerabat (anak, kemekanan, dan saudara kandung/misan), maka bentuknya terdiri dari orang pertama jamak eksklusif am diikuti penanda pronomina persona pertama jamak eksklusif - $a$ - dan sumu 'mulut' sebagai benda yang dimiliki serta diakhiri -mam sebagai bentuk kepemilikan persona pertama jamak eksklusif. Selain penggunaan kepemilikan seperti contoh (8) di atas, bentuk kepemilikan -mam tidak lagi dirangkaikan dengan bentuk persona pertama jamak eksklusif am, melainkan hanya dirangkaikan dengan penanda persona pertama jamak $a$ - membentuk kata amam 'kepunyaan kami' dan diikuti benda yang dimiliki yang merupakan kekerabatan, benda hidup, dan juga benda mati lainnya, contoh (9) dan (10).

Kepemilikan persona pertama jamak inklusif bahasa Patani terdiri atas tiga bentuk, yaitu -r, -nir dan -nor. Bentuk kepemilikan -r digunakan untuk benda yang dimiliki yang merupakan anggota tubuh (kecuali bulu dan buah dada) dan kekerabatan (anak, kemenakan, dan saudara kandung dan saudara misan). Penggunaan bentuk ini dapat dilihat pada contoh berikut.

Online at https://journal.universitasbumigora.ac.id/index.php/humanitatis/

DOI $\quad$ : https://doi.org/10.30812/humanitatis.v8i1.1558 


$$
\begin{aligned}
& \text { It - } i \text { - gye }-r \\
& \text { 1j.ink p1j.ink kaki 1j.ink.pos1 } \\
& \text { 'kaki kita' }
\end{aligned}
$$

Untuk menyatakan kepemilikan bagi persona pertama jamak inklusif, tidak hanya diungkapkan dengan penanda persona pertama jamak inklusif $-i$ - saja tetapi turut digunakan persona pertama jamak inklusif it yang diikuti benda yang dimiliki dan diakhiri dengan bentuk kepemilikan -r membentuk kata nomina posesif itigyer 'kaki kita'.

Bentuk kepemilikan -nir (pos2) digunakan untuk benda hidup dan benda mati yang bukan berupa makanan dan benda yang tidak ada keterkaitan dengan makanan, sebagaimana contoh di bawah ini.

$$
\begin{aligned}
& \text { It -nir angan } \\
& \text { 1j.ink 1j.in.pos2 nenek } \\
& \text { 'nenek kita' } \\
& \text { It -nir yel } \\
& \text { 1j.ink 1j.ink.pos } 2 \text { perahu } \\
& \text { 'perahu kita' }
\end{aligned}
$$

Kepemilikan bagi persona pertama jamak inklusif bentuk -nir tidak lagi disisip penanda persona pertama jamak seperti $-i-$, melainkan hanya diawali dengan persona pertama jamak inklusif it yang diikuti dengan bentuk kepemilikan -nir membentuk kata itnir 'kepunyaan kita'.

Bentuk kepemilikan -nor (pos3) digunakan pada benda berupa makanan maupun benda yang memiliki keterkaitan dengan makanan. Bentuk tersebut dapat dilihat pada contoh sebagai berikut:

$$
\begin{aligned}
& \text { It -nor tele foyno niwi } \\
& \text { 1j.ink 1j.ink.pos pisang santan } \\
& \text { 'pisang santan ( makanan tradisional) kita' } \\
& \text { It -nor kas } \\
& \text { 1j.ink 1j.ink.pos3 lemari makan } \\
& \text { 'lemari makan kita' }
\end{aligned}
$$

Sama seperti kepemilikan persona pertama jamak inklusif bentuk -nir, bentuk -nor tidak lagi disisip penanda persona pertama jamak seperti $-i$-, melainkan hanya diawali dengan persona pertama jamak inklusif it yang diikuti dengan bentuk kepemilikan -nor membentuk kata itnor 'kepunyaan kita'.

\subsection{Bentuk Kepemilikan Persona Kedua Tunggal}

Bentuk kepemilikan persona kedua tunggal bahasa Patani adalah -m, -nim, dan -nam. Bentuk m digunakan untuk benda yang dimiliki merupakan anggota tubuh (kecuali bulu dan buah dada) dan kekerabatan (anak, kemenakan, dan saudara kandung dan saudara misan). Bentuk kepemilikan ini dapat dilihat pada contoh berikut.

Online at https://journal.universitasbumigora.ac.id/index.php/humanitatis/

DOI $\quad$ : https://doi.org/10.30812/humanitatis.v8i1.1558 


$$
\begin{aligned}
& \text { a- boko -m } \\
& \text { p2t kepala 2t.pos1 } \\
& \text { 'kepala kamu' (contoh anggota tubuh) } \\
& a \text { - ftene } \quad \boldsymbol{m} \\
& \text { p2t saudara pr 2t.pos1 } \\
& \text { 'saudara perempuan kamu' (contoh kekerabatan) }
\end{aligned}
$$

Bentuk $a$ - pada contoh di atas merupakan penanda persona kedua tunggal yang diikuti dengan boko 'kepala' (anggota tubuh) contoh (16), ftene 'saudara perempuan' (kekerabatan) contoh (17) sebagai benda yang dimiliki dan bentuk posesif $\mathbf{- m}$ sebagai bentuk kepemilikan orang kedua tunggal.

Bentuk kepemilikan -nim digunakan pada benda hidup dan benda mati yang bukan makanan dan yang tidak memiliki keterkaitan dengan makanan.

Sebagai contoh.

$$
\begin{aligned}
& \text { a- -nim boki } \\
& \text { p2t 2t.pos2 kucing } \\
& \text { 'kucing kamu' } \\
& \text { a- -nim ulut } \\
& \text { p2t 2t.pos2 sarung } \\
& \text { 'sarung kamu' }
\end{aligned}
$$

Bentuk $a$ - merupakan penanda persona kedua tunggal yang dirangkaikan dengan bentuk kepemilikan orang kedua tunggal -nim (pos2) menjadi anim 'kepunyaan kamu' membentuk satu kata dan diikuti benda yang dimiliki yang berdiri sendiri sehingga membentuk frase nomina posesif anim boki 'kucing kamu dan anim ulut 'sarung kamu'.

Bentuk kepemilikan -nam (pos3) digunakan pada benda berupa makanan maupun benda yang memiliki keterkaitan dengan makanan. Bentuk tersebut dapat dilihat pada contoh sebagai berikut:

$$
\begin{aligned}
& \text { a- -nam yof } \\
& \text { p2t 2t.pos3 sagu } \\
& \text { 'sagu kamu' } \\
& \text { a- -nam gow } \\
& \text { P2t 2t.pos3 piring } \\
& \text { 'piring kamu' }
\end{aligned}
$$

Bentuk $\boldsymbol{a}$ - merupakan penanda persona kedua tunggal yang diikuti dengan -nam sebagai bentuk kepemilikian membentuk kata anam 'kepunyaan kamu'. Benda yang dimiliki yang mengikuti anam merupakan benda yang berupa makanan yof 'sagu' contoh (20) dan benda yang memiliki keterkaitan dengan makanan, gow 'piring' seperti contoh (21) di atas.

Online at https://journal.universitasbumigora.ac.id/index.php/humanitatis/

DOI $\quad$ : https://doi.org/10.30812/humanitatis.v8i1.1558 


\subsection{Bentuk Kepemilikan Persona Kedua Jamak}

Dalam bahasa Patani, bentuk kepemilikan persona kedua jamak adalah -me, -nimi dan nomo. Bentuk -me digunakan pada benda berupa anggota tubuh dan kekerabatan (anak, saudara kandung/misan dan kemenakan) seperti dapat dilihat pada contoh berikut.

$$
\begin{aligned}
& \text { Me- mto -me } \\
& \text { p2j mata 2j.pos1 } \\
& \text { 'mata kalian' } \\
& \text { Me- ftene -me } \\
& \text { p2j saudara pr } 2 \mathbf{j} \cdot \mathbf{p o s} 1 \\
& \text { 'saudara pr kalian }
\end{aligned}
$$

Bentuk me- pada contoh di atas merupakan penanda persona kedua jamak yang diikuti dengan mto 'mata' (anggota tubuh) contoh (22), ftene 'saudara perempuan' (kekerabatan) contoh (23) sebagai benda yang dimiliki dan bentuk posesif -me sebagai bentuk kepemilikan orang kedua jamak.

Bentuk kepemilikan -nimi (pos2) digunakan untuk benda hidup dan benda mati yang bukan berupa makanan dan benda yang tidak ada keterkaitan dengan makanan, sebagaimana contoh di bawah ini.

$$
\begin{aligned}
& \text { Me-nimi takale } \\
& \text { p2j 2j.pos2 ayam } \\
& \text { 'ayam kalian' } \\
& \text { Me- - } \text { nimi sise } \\
& \text { p2j 2j.pos } 2 \text { sisir } \\
& \text { 'sisir kalian' }
\end{aligned}
$$

Bentuk me- merupakan penanda persona kedua jamak yang diikuti dengan bentuk -nimi sebagai bentuk kepemilikan membentuk kata menimi 'kepunyaan saya'. Bentuk kepemilikan ini terletak sebelum kata benda yang dimiliki takale 'ayam' contoh (24) yang merupakan benda hidup dan sise 'sisir' contoh (25) yang merupakan benda mati.

Bentuk kepemilikan -nomo (pos3) digunakan pada benda berupa makanan maupun benda yang memiliki keterkaitan dengan makanan. Bentuk tersebut dapat dilihat pada contoh sebagai berikut:

$$
\begin{aligned}
& \text { Me -nomo pinye } \\
& 2 \mathrm{j} \quad \mathbf{2 j} \cdot \mathbf{p o s} 2 \text { nasi } \\
& \text { 'nasi kalian' }
\end{aligned}
$$




$$
\begin{aligned}
& \text { Me -nomo gowgowo } \\
& 2 \mathrm{j} \quad \mathbf{2 j} \text {.pos2 rak piring } \\
& \text { 'rak piring kalian' }
\end{aligned}
$$

Bentuk me- merupakan penanda persona kedua jamak yang diikuti dengan -nomo sebagai bentuk kepemilikian membentuk kata menomo 'kepunyaan kalian'. Benda yang dimiliki yang mengikuti menomo merupakan benda yang berupa makanan pinye 'nasi' contoh (26) dan benda yang memiliki keterkaitan dengan makanan, gowgowo 'rak piring' seperti contoh (27) di atas.

\subsection{Bentuk Kepemilikan Persona Ketiga Tunggal}

Bentuk kepemilikan persona pertama tunggal dalam bahasa Patani adalah -i, -ni, dan -no. Bentuk -i digunakan ketika benda yang dimiliki merupakan anggota tubuh (kecuali bulu dan buah dada) dan kekerabatan (anak, kemenakan, dan saudara kandung dan saudara misan). Bentuk kepemilikan ini dapat dilihat pada contoh berikut.

$$
\begin{aligned}
& \text { I- } \quad \text { boko } \\
& \text { 3t.pos1 kepala } \\
& \text { 'kepala dia' } \\
& \text { I- } \quad \text { ntu } \\
& \text { 3t.pos1 anak } \\
& \text { 'anak dia' }
\end{aligned}
$$

Bentuk i- merupakan persona ketiga tunggal. Dalam hal kepemilikan, bentuk i- ini juga digunakan sebagai bentuk kepemilikan untuk persona ketiga tunggal. Untuk menyatakan kepemilikan maka bentuk i- (pos1) sebagai bentuk kepemilikan dirangkaikan dengan benda yang dimiliki membentuk kata nomina posesif iboko 'kepala dia'. Karena bentuk i merupakan persona ketiga tunggal dan juga sebagai bentuk kepemilikan persona ketiga tunggal, untuk itu dalam hal kepemilikan bentuk i- ini menjadi proklitik.

Bentuk kepemilikan persona ketiga tunggal berikutnya adalah -ni. Bentuk -ni digunakan pada benda hidup dan benda mati (benda bukan makanan dan benda yang tidak memiliki keterkaitan dengan makanan). Penggunaan bentuk kepemilikan -ni dapat dilihat pada contoh berikut.

$$
\begin{aligned}
& \text { I -ni kaya } \\
& \text { 3t 3t.pos2 kakek } \\
& \text { 'kakek dia' }
\end{aligned}
$$

Online at https://journal.universitasbumigora.ac.id/index.php/humanitatis/

DOI : https://doi.org/10.30812/humanitatis.v8i1.1558 


$$
\begin{aligned}
& \text { I -ni yete lol } \\
& \text { 3t 3t.pos2 parang } \\
& \text { 'parang dia' }
\end{aligned}
$$

Bentuk I merupakan persona ketiga tunggal yang diikuti dengan bentuk -ni (pos2) sebagai bentuk kepemilikan membentuk kata ini 'kepunyaan dia'. Bentuk kepemilikan ini terletak sebelum kata benda yang dimiliki kaya 'kakek' yang merupakan benda hidup contoh (30), yete lol 'parang' contoh (31) yang merupakan benda mati.

Bentuk kepemilikan -no (pos3) digunakan untuk makanan dan benda lain yang memiliki keterkaitan dengan makanan. Berikut contoh penggunaan bentuk -no.

$$
\begin{aligned}
& \text { I -no daso } \\
& \text { 3t 3t.pos3 ubi jalar } \\
& \text { 'ubi jalar dia' } \\
& \text { I -no pang } \\
& \text { 3t 3t.pos3 panci } \\
& \text { 'panci dia' }
\end{aligned}
$$

Bentuk I merupakan penanda persona ketiga tunggal yang diikuti dengan -no sebagai bentuk kepemilikian membentuk kata ino 'kepunyaan dia'. Benda yang dimiliki yang mengikuti ino merupakan benda yang berupa makanan daso 'ubi jalar' contoh (32) dan benda yang memiliki keterkaitan dengan makanan pang 'panci' seperti contoh (33) di atas.

\subsection{Bentuk Kepemilikan Persona Ketiga Jamak}

Dalam bahasa Patani, bentuk kepemilikan persona ketiga jamak adalah -re, -niri dan noro. Bentuk -re digunakan pada benda berupa anggota tubuh dan kekerabatan (anak, saudara kandung/misan dan kemenakan) seperti dapat dilihat pada contoh berikut.

$$
\begin{aligned}
& \text { Si gye -re } \\
& \text { 3j kaki 3j.pos1 } \\
& \text { 'kaki mereka' } \\
& \text { Si ftene -re } \\
& \text { 3j saudara pr 3j.pos1 } \\
& \text { 'saudara perempuan mereka' }
\end{aligned}
$$

Bentuk Si- pada contoh di atas merupakan persona ketiga jamak yang diikuti dengan gye 'kaki' (anggota tubuh) contoh (34), ftene 'saudara perempuan' (kekerabatan) contoh (35) sebagai benda yangdimiliki dan bentuk posesif -re sebagai bentuk kepemilikan orang ketiga jamak.

Online at https://journal.universitasbumigora.ac.id/index.php/humanitatis/

DOI : https://doi.org/10.30812/humanitatis.v8i1.1558 
Bentuk kepemilikan -niri (pos2) digunakan untuk benda hidup dan benda mati yang bukan berupa makanan dan benda yang tidak ada keterkaitan dengan makanan, sebagaimana contoh di bawah ini.

$$
\begin{aligned}
& \text { Si -niri kaya re angan } \\
& \text { 3j 3j.pos2 kakek dan nenek } \\
& \text { 'kakek dan nenek mereka' } \\
& \text { Si -niri bibolo } \\
& \text { 3j 3j.pos2 tempat tidur } \\
& \text { 'tempat tidur mereka' }
\end{aligned}
$$

Bentuk $S i$ merupakan persona ketiga jamak yang diikuti dengan bentuk -niri sebagai bentuk kepemilikan membentuk kata siniri 'kepunyaan mereka'. Bentuk kepemilikan ini terletak sebelum kata benda yang dimiliki kaya re angan 'kakek dan nenek' contoh (36) yang merupakan benda hidup dan bibolo 'tempat tidur' contoh (37) yang merupakan benda mati.

Bentuk kepemilikan -noro (pos3) digunakan pada benda berupa makanan maupun benda yang memiliki keterkaitan dengan makanan. Bentuk tersebut dapat dilihat pada contoh sebagai berikut:

$$
\begin{aligned}
& \text { Si -noro yof re in } \\
& 3 \mathrm{j} \mathbf{3 j} \text {.pos3 sagu dan ikan } \\
& \text { 'sagu dan ikan mereka' } \\
& \text { Si -noro botol niwi tanga } \\
& \text { 3j } \mathbf{3 j} \text {.pos3 botol minyak kelapa } \\
& \text { 'botol minyak kelapa mereka' }
\end{aligned}
$$

Bentuk Si merupakan penanda persona ketiga jamak yang diikuti dengan -noro sebagai bentuk kepemilikian membentuk kata sinoro 'kepunyaan mereka'. Benda yang dimiliki yang mengikuti sinoro merupakan benda yang berupa makanan yof re in 'sagu dan ikan' contoh (38) dan benda yang memiliki keterkaitan dengan makanan, botol niwi tanga 'botol minyak kelapa' seperti contoh (39) di atas.

Bentuk-bentuk kepemilikan bahasa Patani sesuai analisis di atas dapat dilihat pada tabel berikut. 
Tabel 2. Bentuk-bentuk Kepemilikan bahasa Patani

\begin{tabular}{|c|c|c|c|c|}
\hline \multirow{3}{*}{ Orang } & \multicolumn{4}{|c|}{ Makna } \\
\hline & \multirow[t]{2}{*}{ Tunggal } & \multicolumn{3}{|c|}{ Jamak } \\
\hline & & Netral & Eksklusif & Inklusif \\
\hline Pertama & $\begin{array}{c}-\mathrm{g} \\
\text {-nik } \\
\text {-nak }\end{array}$ & & -mam & $\begin{array}{l}\text {-r } \\
\text {-nir } \\
\text {-nor }\end{array}$ \\
\hline Kedua & $\begin{array}{l}\text {-m } \\
\text {-nim } \\
\text {-nam }\end{array}$ & $\begin{array}{l}\text {-me } \\
\text {-nimi } \\
\text {-nomo }\end{array}$ & & \\
\hline Ketiga & $\begin{array}{l}\text { i- } \\
-n i \\
-n o\end{array}$ & $\begin{array}{l}\text {-re } \\
\text {-niri } \\
\text {-noro }\end{array}$ & & \\
\hline
\end{tabular}

\section{KESIMPULAN}

Berdasarkan hasil analisis dapat disimpulkan bentuk-bentuk kepemilikan bahasa Patani adalah g, -nik, -nak, -mam, -r, -nir, -nor, -m, -nim, -nam, -me, -nimi, -nomo, i-, -ni, -no, -re, -niri, dan noro. Bentuk kepemilikan tersebut berupa bentuk terikat yang sebagian besar merupakan enklitik. Bentuk kepemilikan yang berbentuk proklitik hanya satu, yaitu bentuk kepemilikan persona ketiga tunggal i-. Bentuk kepemilikan i-, selain sebagai persona ketiga tunggal juga merupakan bentuk kepemilikan.

\section{DAFTAR PUSTAKA}

57Tahun2014PP @ @ jdih.kemenkeu.go.id. (n.d.). https://jdih.kemenkeu.go.id/fullText/2014/57TAHUN2014PP.HTM

Awaluddin. (2017). Pengembangan Buku Teks Bahasa Indonesia. Deepublish.

Duwila, E. dan J. N. (2020). Konstruksi Posesif dalam Bahasa Melayu Ternate.

Imelda. (2017). Bahasa Ibu yang Kehilangan 'Ibu': kajian Sosiolinguistis Bahasa yang Terancam Punah di Maluku Utara.

Koentjono, D. (1982). Dasar-Dasar Linguistik Umum. Fakultas Sastra Universitas Indonesia.

Ramlan, M. (2001). Ilmu Bahasa Indonesia: Morfologi. C.V. Karyono.

Salamun, T. (2019). Perbandingan Pola Konstruksi Posesif Dialek Ambon dengan Bahasa Indonesia $B a k u$. Universitas Igra Buru.

Setiawan, T. (2016). Konstruksi Posesif Bahasa Indonesia dalam Rubrik Surat Pembaca. Universitas Negeri Yogyakarta.

Online at https://journal.universitasbumigora.ac.id/index.php/humanitatis/

DOI : https://doi.org/10.30812/humanitatis.v8i1.1558 
Online at https://journal.universitasbumigora.ac.id/index.php/humanitatis/

DOI : https://doi.org/10.30812/humanitatis.v8i1.1558 